\title{
PREDICTION OF THE ELASTIC MODULI OF CHICKEN-FEATHER-REINFORCED PLA AND A COMPARISON WITH EXPERIMENTAL RESULTS
}

\author{
NAPOVEDOVANJE MODULOV ELASTIČNOSTI PLA, OJAČANEGA \\ $S$ PIŠČANČJIM PERJEM IN PRIMERJAVA Z \\ EKSPERIMENTALNIMI REZULTATI
}

\author{
Ŭgur Özmen, Buket Okutan Baba \\ Celal Bayar University, Engineering Faculty, Mechanical Engineering Department, 45140 Muradiye/Manisa, Turkey \\ u.ozmen@hotmail.com
}

Prejem rokopisa - received: 2014-08-07; sprejem za objavo - accepted for publication: 2015-03-04

doi:10.17222/mit.2014.182

\begin{abstract}
The purpose of this study is to obtain the elastic moduli, the key material property, of random discontinuous fiber composites with experiments and micromechanical models and to compare them. The proposed study makes it possible to assess the elastic moduli of chicken-feather fiber (CFF)/PLA green composites with different CFF mass fractions and to determine the feasibility of the micromechanical models for the CFF/PLA composites. For this purpose, initially, CFF/PLA composites including 2, 5 or $10 \%$ chicken-feather mass fractions were extruded and standard tensile specimens for ISO 527 were formed with the injection-molding method. Tensile tests were carried out in accordance with the standards and the elastic moduli were calculated using the stress-strain curve. Then, using six different micromechanical models, the elastic moduli of the CFF/PLA composites with different mass fractions were calculated and compared with the experimental results. The results of the experiments and the models indicated that the presence of chicken feather increased the elastic moduli of all the composites in comparison with the pure PLA. According to the experimental data, the maximum increase in the elastic moduli of the composites with the presence of CFF was found to be $5.4 \%$. The maximum error in the prediction is about $16.8 \%$ for the composite with a chicken-feather rate of $10 \%$ when Manera's model is used. Among the micromechanical models, the ones that gave more converging results for the prediction of the elastic moduli of the CFF/PLA composites are Pan's 2-D, IROM (the inverse rule of mixtures), Nielsen-Chen and Halpin-Tsai models. A comparison of the results of these six models shows that the maximum deviation (the percentage error in prediction) is the smallest $(1.4 \%)$ for the Nielsen-Chen model. Therefore, the Nielsen-Chen model is the most appropriate model for the prediction of the elastic moduli of the CFF/PLA composites.

Keywords: chicken feather, PLA, green composite, micromechanical models
\end{abstract}

Namen te študije je dobiti module elastičnosti kot glavne lastnosti materiala, kompozitov z naključnimi vlakni, z eksperimenti in z mikromehanskimi modeli ter njihova primerjava. Predlagana študija bo omogočila določitev modula elastičnosti kompozita iz vlaken piščančjega perja (CFF)/PLA, z različnim masnim deležem CFF in ugotoviti izvedljivost mikromehanskih modelov za CFF/PLA kompozite. V ta namen so bili najprej kompoziti CFF/PLA z $2 \%, 5 \%$ in $10 \%$ piščančjih peres, ekstrudirani in izdelani so bili standardni natezni preizkušanci po ISO 527, z metodo brizganja v formo. Natezni preizkusi so bili izvršeni v skladu s standardom in modul elastičnosti je bil izračunan iz krivulje napetost-raztezek. Nato so bili izračunani moduli elastičnosti kompozita CFF/PLA, z uporabo šestih različnih mikromehanskih modelov in primerjani z rezultati preizkusov. Rezultati preizkusov in modelov so pokazali, da prisotnost piščančjih peres poveča modul elastičnosti vseh kompozitov, $\mathrm{V}$ primerjavi s čistim PLA. Eksperimentalni podatki so pokazali, da je največje povečanje modula elastičnosti kompozita s CFF za $5,4 \%$. Pri uporabi Manera modela je bila največja napovedana napaka okrog 16,8\% pri kompozitu z $10 \%$ deležem piščančjega perja. Med mikromehanskimi modeli, ki imajo največji raztros rezultatov pri napovedovanju modula elastičnosti CFF/PLA kompozitov so Pan's 2-D, IROM (Inverse Rule of Mixtures), Nielsen-Chen in Halpin-Tsai model. Primerjava rezultatov teh šestih modelov kaže, da je največje odstopanje (odstotek pri napovedi) najmanjše $(1,4 \%)$ pri Nielsen-Chen modelu. Torej je Nielsen-Chen model najbolj primeren za napovedovanje modula elastičnosti CFF/PLA kompozitov.

Ključne besede: piščančje perje, PLA, zelen kompozit, mikromehanski modeli

\section{INTRODUCTION}

Since the straw-reinforced cement in the antique ages, random discontinuous short-fiber-reinforced composites have always existed. ${ }^{1}$ A lot of experimental studies have been done on this subject. Many are about natural-fiber-reinforced ones because of the structure of natural fibers that cannot be converted into long fibers. Waste-based, ${ }^{2}$ synthetic-based, ${ }^{3}$ plant-based ${ }^{4-7}$ and animal-based $^{8-12}$ fibers have been studied by many researchers. Experimental studies are substantially important to get the highest efficiency from the random discontinuous short-fiber-reinforced composites. Experimental studies are still hard to perform, as time-consuming and costly tests need to be done to characterize the composite materials. ${ }^{13}$ Therefore, researchers developed certain micromechanical models for calculating the properties of the composites to avoid a great number of tests. Modelling of the random discontinuous short-fiber-reinforced composites is quite hard compared to the long and oriented ones. For the situations where the well-known method named the rule of mixtures for predicting the elastic moduli of composite materials could not provide proper predictions, 
Table 1: Tensile-test specimens of composites with different chicken-feather mass fractions Tabela 1: Natezni preizkušanci kompozitov z različnim masnim deležem piščančjega perja

\begin{tabular}{|c|c|}
\hline Pure PLA & \\
\hline Tensile specimens containing $2 \%$ of chicken feather & \\
\hline Tensile specimens containing $5 \%$ of chicken feather & Tor \\
\hline Tensile specimens containing $10 \%$ of chicken feather & Sor \\
\hline
\end{tabular}

Christensen and Waals, ${ }^{14}$ Pan, ${ }^{15}$ Manera, ${ }^{16}$ NielsenChen $^{17}$ and Halpin-Tsai ${ }^{18,19}$ proposed new models based on the rule of mixtures. While for some models the range of validity is limited to specific mass fractions, other models are different. Although each of these models was developed for all the random discontinuous short-fiberreinforced composites, they may give unexpected results for some of the composites.

The purpose of this study is to predict the elastic moduli of the composites with different chicken-feather mass content via the models developed for random discontinuous short-fiber-reinforced composites. The volume fractions, with which these models express their sensitive results, were investigated and the volume-fraction range for these composite materials was determined.

\section{EXPERIMENTAL WORK}

Two materials were used for the composites, poly lactic acid (PLA) as the matrix and chicken-feather fibers (CFFs) as the reinforcement. The CFFs were procured from a local company in Manisa/Turkey. The
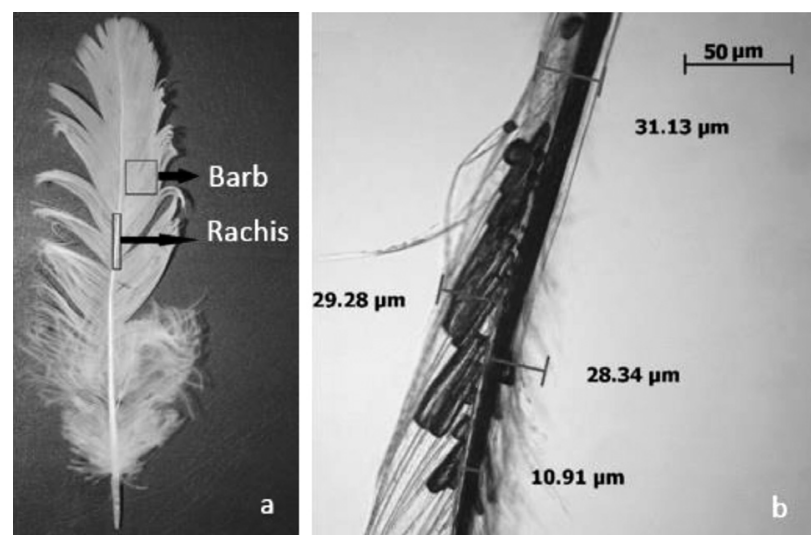

Figure 1: a) Parts of a chicken feather, b) light-microscope image of the barb

Slika 1: a) Deli piščančjega peresa, b) svetlobni posnetek stržena peresa in perja
CFFs (or barbs) were separated from the rachis (Figure 1a). They were washed with hot water for sterilization and kept in water for $24 \mathrm{~h}$. Then, the CFFs were kept in an oven at $60{ }^{\circ} \mathrm{C}$ for $6 \mathrm{~h}$ in order to dehumidify them. The lengths of the CFFs varied from $10 \mathrm{~mm}$ to $30 \mathrm{~mm}$. Their diameters were measured to be approximately 20-40 $\mu \mathrm{m}$ using a light microscope (Figure 1b). The PLA was purchased from Resinex BMY AS in Istanbul/Turkey. The type of the PLA was NatureWorks $3052 \mathrm{D}$ with a density of $1.24 \mathrm{~g} / \mathrm{cm}^{3}$.

The CFF/PLA composites with CFF mass fractions of $(2,5$ and 10$) \%$ were manufactured by extrusion. Initially, the PLA granules and the CFFs were mixed with a mechanical mixer. The mixtures were extruded using a

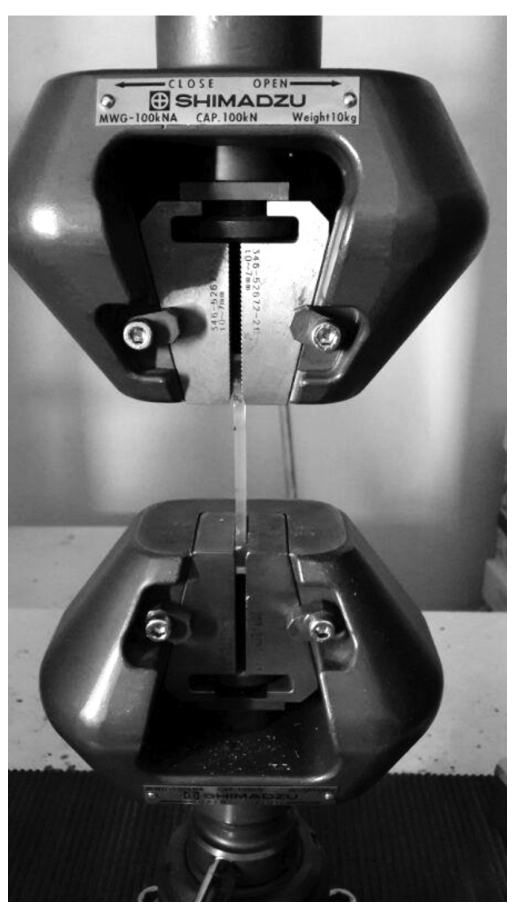

Figure 2: Specimen during the tensile test Slika 2: Vzorec med nateznim preizkusom 
ThermoFisher Scientific EuroLab 16 XL twin-screw extruder. The barrel temperature-zone profile and the screw speed were $165 / 175 / 185 / 195 / 205{ }^{\circ} \mathrm{C}$ and 150 $\mathrm{min}^{-1}$, respectively. Following the extrusion process, the composites were chopped, with a pelletizer, into pieces with a length of $0.3 \mathrm{~cm}$. Then, the granules were manufactured as the tensile specimens in line with the ISO 527 standards, with a PERMAK injection-molding machine. The barrel temperatures and pressure were 154/160/154 ${ }^{\circ} \mathrm{C}$ and 147 bar, respectively. The tensile specimens are shown in Table $\mathbf{1 .}$

The length of the tensile specimens was $88 \mathrm{~mm}$, the width of the narrow and wide sections was 5 and $10 \mathrm{~mm}$, respectively. The thickness of the specimens was $4 \mathrm{~mm}$ and the gage length was $40 \mathrm{~mm}$. The tensile test was conducted to determine the elastic moduli of the composites. Each specimen was tested at a speed of $1 \mathrm{~mm} / \mathrm{min}$, using a $100 \mathrm{kN}$ Shimadzu Autograph testing machine (Figure 2). At least five identical specimens were tested per specimen type.

\section{MICROMECHANICAL MODELS}

The micromechanical models that can predict the elastic moduli of random discontinuous fiber composites are presented below.

The fiber volume fraction $\left(V_{\mathrm{f}}\right)$ used in the equations is calculated as follows: ${ }^{13}$

$$
V_{\mathrm{f}}=\frac{\frac{M_{\mathrm{f}}}{\rho_{\mathrm{f}}}}{\frac{M_{\mathrm{f}}}{\rho_{\mathrm{f}}}+\frac{M_{\mathrm{c}}-M_{\mathrm{f}}}{\rho_{\mathrm{m}}}}
$$

where $M_{\mathrm{f}}$ and $\rho_{\mathrm{f}}$ indicate the mass and the density of the fiber material. $M_{\mathrm{c}}$ indicates the mass of the composite material and $\rho_{\mathrm{m}}$ indicates the density of the matrix.

\subsection{Christensen-Waals model}

Christensen and Waals ${ }^{14}$ investigated a compositematerial system whose random fiber orientation has three dimensional directions. They considered both the fiber orientation and the fiber/matrix interaction. They calculated the elastic moduli of the composite materials with low fiber fractions for the plane stress using the formula below:

$$
E=\frac{c}{3} E_{\mathrm{f}}+(1+c) E_{\mathrm{m}} \quad \mathrm{c}<0.2
$$

where $E$ indicates the elastic modulus of the composite material, $E_{\mathrm{f}}$ indicates the elastic modulus of the fiber material, $E_{\mathrm{m}}$ indicates the elastic modulus of the matrix material and $c$ indicates the fiber volume fraction.

\subsection{Pan's model}

$\operatorname{Pan}^{15}$ put forward a new approach for the prediction of the elastic moduli of the randomly oriented fiber composites. First, he used the rule of mixtures for the parts where the fibers were not unidirectional; he used the relationship between the fiber volume fraction and the fiber-area ratio. He obtained the equations below for 2and 3-dimensional cases:

$$
\begin{gathered}
E^{2 \mathrm{D}}=E_{\mathrm{f}} V_{\mathrm{f}} \frac{1}{\pi}+E_{\mathrm{m}}\left(1-\frac{1}{\pi} V_{\mathrm{f}}\right) \\
E^{3 \mathrm{D}}=E_{\mathrm{f}} V_{\mathrm{f}} \frac{1}{2 \pi}+E_{\mathrm{m}}\left(1-\frac{1}{2 \pi} V_{\mathrm{f}}\right)
\end{gathered}
$$

where, $E$ indicates the elastic modulus of the composite material, $E_{\mathrm{f}}$ indicates the elastic modulus of the fiber material, $E_{\mathrm{m}}$ indicates the elastic modulus of the matrix material and $V_{\mathrm{f}}$ indicates the fiber volume fraction.

\subsection{Inverse rule of mixtures (IROM)}

The rule-of-mixtures model is frequently used to predict the elastic moduli of the composite materials with continuous and unidirectional fibers. Since the inverse rule of mixtures indicates that the loading is perpendicular to the fibers, it is used to predict the elastic moduli of the random discontinuous short-fiber-reinforced composites in this study. ${ }^{13}$ The inverse rule of mixtures is expressed as:

$$
E=\left(\frac{V_{\mathrm{f}}}{E_{\mathrm{f}}}+\frac{1-V_{\mathrm{f}}}{E_{\mathrm{m}}}\right)^{-1}
$$

where $E$ indicates the elastic modulus of the composite material, $E_{\mathrm{f}}$ indicates the elastic modulus of the fiber material, $E_{\mathrm{m}}$ indicates the elastic modulus of the matrix material and $V_{\mathrm{f}}$ indicates the fiber volume fraction.

\subsection{Manera's model}

Manera $^{16}$ developed a new equation by making some assumptions on Puck's micromechanical model and simplifying it. These assumptions include a high fiber orientation ratio, two-dimensional random-fiber range, and he also considered the randomly oriented discontinuous fibers as the laminate of an unlimited number of layers. Manera's equation is as follows:

$$
E=V_{\mathrm{f}}\left(\frac{16}{45} E_{\mathrm{f}}+2 E_{\mathrm{m}}\right)+\frac{8}{9} E_{\mathrm{m}}
$$

where $E$ indicates the elastic modulus of the composite material, $E_{\mathrm{f}}$ indicates the elastic modulus of the fiber material, $E_{\mathrm{m}}$ indicates the elastic modulus of the matrix material and $V_{\mathrm{f}}$ indicates the fiber volume fraction.

\subsection{Nielsen-Chen model}

Nielsen and Chen built a new model for the prediction of the elastic moduli of the composite materials using the rule of mixtures and the inverse rule of mixtures: ${ }^{17}$ 
U. ÖZMEN, B. OKUTAN BABA: PREDICTION OF THE ELASTIC MODULUS OF CHICKEN-FEATHER-REINFORCED PLA ...

$$
E=\frac{3}{8} E_{\Pi}+\frac{5}{8} E_{\perp}
$$

where;

$$
\begin{aligned}
& E_{\Pi}=E_{\mathrm{f}} V_{\mathrm{f}}+E_{\mathrm{m}}\left(1-V_{\mathrm{f}}\right) \\
& E_{\perp}=\frac{E_{\mathrm{f}} E_{\mathrm{m}}}{E_{\mathrm{f}}\left(1-V_{\mathrm{f}}\right)+V_{\mathrm{f}} E_{\mathrm{m}}}
\end{aligned}
$$

and $E$ indicates the elastic modulus of the composite material, $E_{\mathrm{f}}$ indicates the elastic modulus of the fiber material, $E_{\mathrm{m}}$ indicates the elastic modulus of the matrix material and $V_{\mathrm{f}}$ indicates the fiber volume fraction.

\subsection{Halpin-Tsai model}

The Halpin-Tsai model is quite complicated in comparison with the other micromechanical models. ${ }^{18,19}$ Its consideration of the aspect ratio is the most important advantage of this model. Therefore, the Halpin-Tsai model converges better to the experimental results. The Halpin-Tsai model is as follows:

$$
E=E_{\mathrm{m}} \frac{1+\xi \eta v_{\mathrm{f}}}{1-\eta v_{\mathrm{f}}}
$$

where $\eta$ and $\xi$ are:

$$
\begin{gathered}
\eta=\frac{\frac{E_{\mathrm{f}}}{E_{\mathrm{m}}}-1}{\frac{E_{\mathrm{f}}}{E_{\mathrm{m}}}+\xi} \\
\xi=\frac{2 L}{D}
\end{gathered}
$$

and $E$ indicates the elastic modulus of the composite material, $E_{\mathrm{f}}$ indicates the elastic modulus of the fiber material, $E_{\mathrm{m}}$ indicates the elastic modulus of the matrix material and $V_{\mathrm{f}}$ indicates the fiber volume fraction. $L$ and $D$ indicate the fiber length and diameter, respectively.

\section{RESULTS AND DISCUSSION}

The elastic moduli of PLA and CFF/PLA composites were obtained with tensile testing and the results are shown in Table 2. The elastic modulus of PLA was

Table 2: Experimental data for the elastic moduli of CFF/PLA composites

Tabela 2: Eksperimentalni podatki za module elastičnosti CFF/PLA kompozita

\begin{tabular}{|c|c|c|}
\hline $\begin{array}{c}\text { Chicken-feather } \\
\text { mass fractions, } \\
(w / \%)\end{array}$ & $\begin{array}{c}\text { Chicken-feather } \\
\text { volume fractions, } \\
\left(V_{\mathrm{f}} / \%\right)\end{array}$ & $\begin{array}{c}\text { Elastic modulus } \\
(E / \mathrm{MPa})\end{array}$ \\
\hline 0 & 0 & $3004(255)$ \\
\hline 2 & 2.76 & $3083(83)$ \\
\hline 5 & 6.83 & $3076(309)$ \\
\hline 10 & 13.4 & $3166(132)$ \\
\hline
\end{tabular}

*The values given in the parentheses are standard deviations.

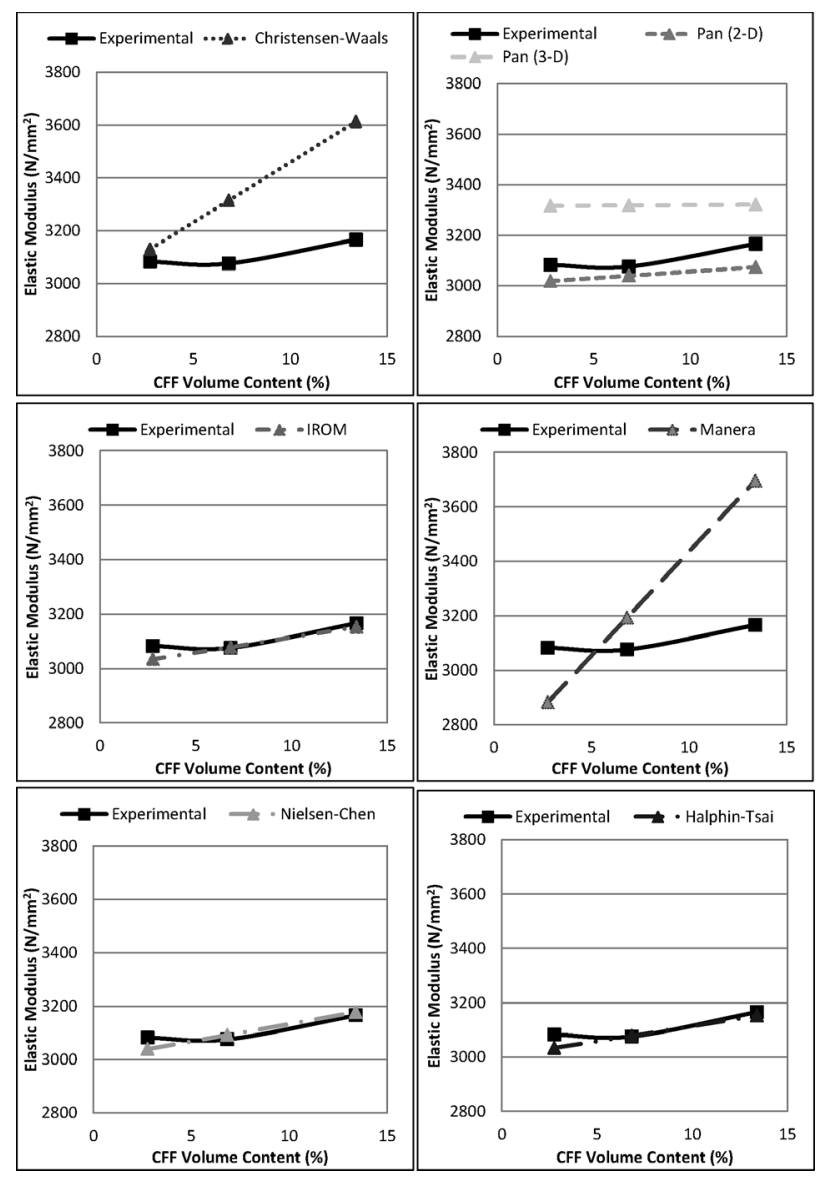

Figure 3: Comparison of the elastic moduli of the composite materials obtained with different micromechanical models

Slika 3: Primerjava modulov elastičnosti kompozitnih materialov,

\begin{tabular}{|c|c|c|c|c|c|c|c|}
\hline 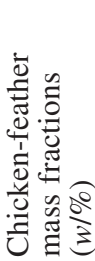 & 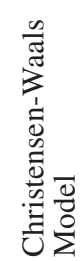 & 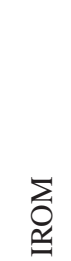 & 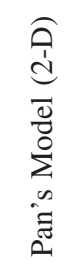 & 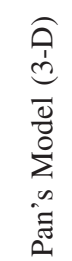 & 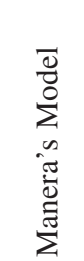 & 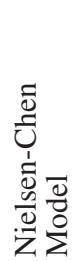 & 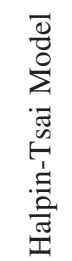 \\
\hline 2 & $\begin{array}{l}3130 \\
(1.7)\end{array}$ & $\begin{array}{l}3034 \\
(1.6)\end{array}$ & $\begin{array}{l}3019 \\
(2.1)\end{array}$ & $\begin{array}{l}3317 \\
(7.6)\end{array}$ & $\begin{array}{l}2882 \\
(6.3)\end{array}$ & $\begin{array}{l}3040 \\
(1.4)\end{array}$ & $\begin{array}{l}3034 \\
(1.6)\end{array}$ \\
\hline 5 & $\begin{array}{l}3315 \\
(7.8)\end{array}$ & $\begin{array}{l}3079 \\
(0.1)\end{array}$ & $\begin{array}{l}3040 \\
(1.2)\end{array}$ & $\begin{array}{l}3319 \\
(7.9)\end{array}$ & $\begin{array}{l}3194 \\
(3.8)\end{array}$ & $\begin{array}{l}3092 \\
(0.5)\end{array}$ & $\begin{array}{l}3079 \\
(0.1)\end{array}$ \\
\hline 10 & $\begin{array}{c}3614 \\
(14.1)\end{array}$ & $\begin{array}{l}3153 \\
(0.4)\end{array}$ & $\begin{array}{l}3074 \\
(2.9)\end{array}$ & $\begin{array}{l}3322 \\
(4.9)\end{array}$ & $\begin{array}{c}3697 \\
(16.8)\end{array}$ & $\begin{array}{l}3179 \\
(0.4)\end{array}$ & $\begin{array}{l}3153 \\
(0.4)\end{array}$ \\
\hline
\end{tabular}
dobljenih iz različnih mikromehanskih modelov

Table 3: Elastic moduli of composite materials obtained with micromechanical models

Tabela 3: Moduli elastičnosti kompozitnih materialov iz mikromehanskih modelov

*The values given in the parentheses are percentage differences between the elastic moduli obtained with the micromechanical models and experiments.

experimentally measured as $3004 \mathrm{MPa}$. The chickenfeather addition increased the elastic modulus by approximately $2.6 \%$ for the mass fraction of $2 \%$, while increasing the elastic modulus by $2.4 \%$ for the mass 
fraction of $5 \%$. Similarly, its increase for the composite materials with a chicken-feather mass fraction of $10 \%$ was $5.4 \%$. The increasing CFF content raised the elastic modulus as expected. This increase in the elastic modulus validated the predictions made with the micromechanical models.

A comparison of the elastic moduli obtained with the models and tests for the composite materials including the chicken-feather mass fractions of $(2,5$ and 10$) \%$ is shown in Table 3. To show the differences between the results of the models and the tests, the elastic moduli from Table $\mathbf{3}$ are plotted as shown in Figure 3. According to the literature, the Christensen-Waals model gives accurate results for some composite materials containing a mass fraction of up to $20 \%$. In this study, the CFF/PLA composites having a mass fraction of $2 \%$ show a deviation of $1.7 \%$, which is a close to the experimental results, as mentioned above. The materials including mass fractions of 5 and $10 \%$ show deviations of $7.8 \%$ and $14.1 \%$, respectively, which means that the results diverge from the experimental data when the mass fraction of the material increases. Consequently, the Christensen-Waals model does not predict the elastic modulus very well for a fiber mass fraction of more than $2 \%$.

IROM shows a deviation of $1.6 \%$ from the prediction of the elastic modulus of the composites including a $2 \%$ chicken-feather content when compared with the experimental results. IROM produces accurate values converging by more than $99 \%$ to the prediction of the elastic moduli of the composites having mass fractions of 5 and $10 \%$. Pan's 2-D model shows the results close to the experimental elastic-modulus values of the composites including (2, 5 and 10) $\%$ of CFF. Their deviations are (2.1, 1.2 and 2.9) \%, respectively. On the other hand, the elastic modulus found with Pan's 3-D model is higher than the test data even at low fiber mass fractions.

Manera's model fails to give good predictions of the elastic modulus for high fiber mass fractions. Therefore, it is not possible to use Manera's model for the prediction of the elastic moduli of the composites including high fiber contents. However, the model gives reasonable predictions for the fiber mass fractions of about $5 \%$. Manera's model exhibits a deviation of $3.8 \%$ for the composite including a mass fraction of $5 \%$.

Another elastic-modulus-prediction model is the Nielsen-Chen model. The predictions of this model are close to the test data. It exhibits deviations of $(1.4,0.5$ and 0.4$) \%$ for the elastic moduli of the composites including (2, 5 and 10$) \%$ of the CFF content, respectively, when compared with the experimental results. Hence, the Nielsen-Chen model is the best model producing the closest and most reliable results among the models investigated in this study. As seen in Figure 2, the Halpin-Tsai model exhibits the results similar to IROM and its deviations are very close to the ones found with IROM. The Halpin-Tsai model is also one of the most appropriate models to predict the elastic moduli of the CFF/PLA composites.

\section{CONCLUSION}

In this study, the elastic moduli of the composites including mass fractions of $(2,5$ and 10$) \%$ of chickenfeather fibers were predicted using six different micromechanical models and the results were compared with the experimental data. The results are given below:

Although the Christensen-Waals model gives good predictions for low fiber mass fractions, it does not fit well the test data for high fiber mass fractions. Pan's 3-D model and Manera's model do not produce reliable results when used to predict the elastic moduli of the CFF/PLA composites.

The comparison with the experimental results shows that Pan's 2-D model, the inverse rule of mixtures and the Halpin-Tsai model can be used to predict the elastic moduli of the CFF/PLA composites.

From the comparison, it can be seen that the Nielsen-Chen model gives the best predictions of the elastic modulus of the CFF/PLA composites. Consequently, the most appropriate model to predict the elastic moduli of the CFF/PLA composites is the Nielsen-Chen model.

\section{Acknowledgements}

This project was supported by the Celal Bayar University Research Funds 2013/35.

\section{REFERENCES}

${ }^{1}$ F. P. La Mantia, M. Morreale, Green composites: A brief review, Composites: Part A, 42 (2011), 579-588, doi:10.1016/j.compositesa. 2011.01.017

${ }^{2}$ M. S. Huda, L. T. Drzal, A. K. Mohanty, M. Misra, Chopped glass and recycled newspaper as reinforcement fibers in injection molded poly(lactic acid) (PLA) composites: A comparative study, Composites Science and Technology, 66 (2006), 1813-1824, doi:10.1016/ j.compscitech.2005.10.015

${ }^{3}$ K. Oksman, M. Skrifvars, J. F. Selin, Natural fibres as reinforcement in polylactic acid (PLA) composites, Composites Science and Technology, 63 (2003), 1317-1324, doi:10.1016/S0266-3538(03) 00103-9

${ }^{4}$ N. Graupner, A. S. Herrmann, J. Müssig, Natural and man-made cellulose fibre-reinforced poly(lactic acid) (PLA) composites: An overview about mechanical characteristics and application areas, Composites: Part A, 40 (2009), 810-821, doi:10.1016/j.compositesa. 2009.04.003

${ }^{5}$ A. K. Bledzki, A. Jaszkiewicz, D. Scherzer, Mechanical properties of PLA composites with man-made cellulose and abaca fibres, Composites: Part A, 40 (2009), 404-412, doi:10.1016/j.compositesa. 2009.01.002

${ }^{6} \mathrm{~S}$. Ochi, Mechanical properties of kenaf fibers and kenaf/PLA composites, Mechanics of Materials, 40 (2008), 446-452, doi:10.1016/j.mechmat.2007.10.006

${ }^{7}$ B. Bax, J. Müssig, Impact and tensile properties of PLA/Cordenka and PLA/flax composites, Composites Science and Technology, 68 (2008), 1601-1607, doi:10.1016/j.compscitech.2008.01.004 
${ }^{8}$ M. P. Ho, K. T. Lau, H. Wang, D. Bhattacharyya, Characteristics of a silk fibre reinforced biodegradable plastic, Composites: Part B, 42 (2011), 117-122, doi:10.1016/j.compositesb.2010.10.007

${ }^{9}$ H. Y. Cheung, K. T. Lau, X. M. Tao, D. Hui, A potential material for tissue engineering Silkworm silk/PLA biocomposite, Composites: Part B, 39 (2008), 1026-1033, doi:10.1016/j.compositesb.2007.11. 009

${ }^{10}$ H. Y. Cheung, K. T. Lau, Y. F. Pow, Y. Q. Zhao, D. Hui, Biodegradation of a silkworm silk/PLA composite, Composites: Part B, 41 (2010), 223-228, doi:10.1016/j.compositesb.2009.09.004

${ }^{11}$ S. Huda, Y. Yang, Composites from ground chicken quill and polypropylene, Composites Science and Technology, 68 (2008), 790-798, doi:10.1016/j.compscitech.2007.08.015

${ }^{12}$ M. Zhan, R. P. Wool, J. Q. Xiao, Electrical properties of chicken feather fiber reinforced epoxy composites, Composites: Part A, 42 (2011), 229-233, doi:10.1016/j.compositesa.2010.11.007

${ }^{13}$ A. K. Kaw, Mechanics of Composite Materials, $2^{\text {nd }}$ ed., Taylor \& Francis Group, New York 2006, 457
${ }^{14}$ R. M. Christensen, F. M. Waals, Effective Stiffness of Randomly Oriented Fiber Composites, Journal of Composite Materials, 6 (1972), 518-532, doi:10.1177/002199837200600307

${ }^{15}$ N. Pan, The elastic constants of randomly oriented fiber composite: A new approach to prediction, Science and Engineering of Composite Materials, 5 (1996) 2, 63-72, doi:10.1515/SECM.1996.5.2.63

${ }^{16}$ M. Manera, Elastic properties of randomly oriented short fiber-glass composites, Journal of Composite Materials, 11 (1977), 235-247, doi:10.1177/002199837701100208

${ }^{17}$ E. Vannan, P. Vizhia, Prediction of the Elastic Properties of Short Basalt Fiber Reinforced Al Alloy Metal Matrix Composites, Journal of Minerals and Materials Characterization and Engineering, 2 (2014), 61-69, doi:10.4236/jmmce.2014.21010

${ }^{18}$ J. E. Ashton, J. C. Halpin, P. H. Petit, Primer on Composite Materials: Analysis, Technomic, Stamford, Conn. 1969

${ }^{19}$ J. C. Halpin, Stiffness and Expansion Estimates for Oriented Short Fiber Composites, Journal of Composite Materials, 3 (1969), 732-734, doi:10.1177/002199836900300419 